\title{
ANTECEDENTS OF DESTINATION IMAGE IN NATURAL PROTECTED AREA: THE MODERATING ROLE OF PERCEIVED VALUE
}

\author{
Ying-Sin CHIN* \\ Universiti Malaysia Sarawak, Faculty of Economics and Business, 94300 Kota Samarahan, Sarawak, Malaysia, e-mail: cynthiachin95@gmail.com
}

\author{
Abang Azlan MOHAMAD
}

Universiti Malaysia Sarawak, Faculty of Economics and Business, 94300 Kota Samarahan, Sarawak, Malaysia, e-mail: maazlan@unimas.my

May-Chiun LO

Universiti Malaysia Sarawak, Faculty of Economics and Business, 94300 Kota Samarahan, Sarawak, Malaysia, e-mail: mclo@unimas.my

Wan Hashim Wan IBRAHIM

Universiti Malaysia Sarawak, Chancellery, 94300 Kota Samarahan, Sarawak, Malaysia, e-mail: wiwhashim@unimas.my

Shiaw-Tong HA

Faculty of Economics and Business, Universiti Malaysia Sarawak, 94300 Kota Samarahan, Sarawak, Malaysia, e-mail: revetong@ gmail.com

Citation: Chin, Y.S., Mohamad, A.A., Lo, M.C., Ibrahim, W.H.W., \& Ha, S.T., (2020). ANTECEDENTS OF DESTINATION IMAGE IN NATURAL PROTECTED AREA: THE MODERATING ROLE OF PERCEIVED VALUE. GeoJournal of Tourism and Geosites, 32(4), 12221228. https://doi.org/10.30892/gtg.32405-561

\begin{abstract}
Ecotourism is a nature-oriented tourism idea that is flourishing and with promising outlook. The present study attempts to explore the importance of local communities' attitude, carrying capacity and destination attractiveness \& resources towards destination image by adopting perceived value as a moderator on examining the antecedents on destination image. Data were collected from 146 tourists who have visited Bako National Park, Sarawak. The research employs WarpPLS 6.0 and the results revealed that local communities' attitude, carrying capacity and destination attractiveness \& resources have impact on destination image. Perceived value has moderating effect between destination attractiveness \& resources and destination image.
\end{abstract}

Key words: local communities' attitude, carrying capacity, destination attractiveness and resources, perceived value, destination image

\section{INTRODUCTION}

Tourism has become a noteworthy part of economic development. As revealed by Andrades and Dimanche (2017), the future economic benefits of tourism to regions or countries have been a recurring topic in the literature on tourism research. Ecotourism is a nature-oriented tourism that is thriving with promising future as it is able to satisfy the needs of tourists. It serves tourists with enriching "experience" that enables them to fulfil their tourism experiences (Lin, 2019). Therefore, the development of ecotourism has become the development direction of various governments to meet tourists' expectations and satisfaction. According to the Ministry of Tourism, Arts and Culture (MOTAC), Malaysia has encountered a rise in terms of visitor arrivals with an inclination rate of $14.66 \%$ among international tourists in 2018 (MOTAC, 2020). Besides, The National Ecotourism Plan 2016-2025 forms part of Visit Malaysia 2020 and was planned to optimize the capacity of ecotourism and ensure the sustainability of tourism (The Star Online) which would further improve the contribution of the tourism industry to the economy given the lackluster results in the first quarter of 2020 with figures adversely affected by the Covid-19 pandemic.

The challenge of sustainable development of ecotourism has emerged as an important and popular theoretical objective to consider the costs, risks and impacts of global environmental hazards on tourism and travel (Jamal and Budke, 2020). Two immense drivers of change are climate change and global health emergencies namely the coronavirus disease (Covid-19) that is currently impacting tourism sector. In addition, national parks are known as ecotourism or recreational tourism destination due to pristine environments with a unique natural formation. Establishing national parks without efficient tourism management could also have a negative impact in protecting and conserving natural areas where it can damage the environment, causing overcrowding and pollution (Buckley, 2011; Tepavčević et al., 2019).

The present study was conducted at Bako National Park situated in Sarawak, Malaysia. According to the Ministry of Tourism, Arts and Culture, Sarawak (MTAC), Bako National Park is the oldest national park in Sarawak and is easily accessible from Kuching. It has proven a hit with foreign and domestic tourists where it has recorded the highest number of tourist arrivals on its diverse biodiversity, unique landscape, and favorable tourism infrastructure. In the light of the above discussion, this study attempts to examine the antecedents of local communities' attitude, carrying capacity and natural resources on destination image in Bako National Park, Sarawak. In addition, perceived value is adopted as a moderator variable to examine the relationship among the constructs. There are no studies investigating on perceived value as a moderator on linking between antecedents and destination image. Therefore, this paper tries to fill the gap by conceptualizing perceived value as a moderator in the relationship between local communities' attitude, carrying capacity and natural resources on destination image. The outcome of the study will provide useful and effective insights for future research.

\section{Literature Review and Development of Hypotheses}

Destination Image

An increasingly strong competitiveness of a destination is focused primarily on the perceived image of its destination (Michaelidou et al.,

\footnotetext{
${ }^{*}$ Corresponding author
} 
2013). Destination image is an attribute of strengthening destination for tourists (Le et al., 2020). This can be described as the sum of a person's beliefs and impressions towards the destination (Chiu et al., 2014). Destination image may be analysed by multi-attribute approach because of its effective identity and holistic images which are influenced by cognitive interpretation of destination attributes (Jiang et al., 2017). The thoughts and feelings of a tourist destination are created, and the forming image of the destination is affected holistically (Veasna et al., 2013; Moon and Han, 2019). Therefore, a good and positive destination image will be a factor that impacts the perception of tourist towards tourism destination. Destination image can generally prove its attraction and satisfy the expectations and satisfaction of the tourists. In addition, previous studies have provided empirical evidence that the destination image is a valuable concept for understanding tourist preferences, selection processes, revisiting intentions and recommendations (Kim and Lee, 2015; Kladou and Mavragani, 2015; Souiden et al., 2017).

\section{Local Communities' Attitude}

The attitude of local communities can be described as the psychological behaviour of local communities through the expression of their favourable or unfavourable attitude towards tourists (Eagly and Chaiken, 1993). The impact of local communities has been recognized as an important aspect of ecotourism (Duffy et al., 2017). In most ecotourism destinations, the community plays an important role as a provider. Their favourable and unfavourable behaviours will enhance the destination's popularity otherwise it will result in negative impression (Abas and Hanafiah, 2014; Chin et al., 2018). Past studies have revealed that local communities are one of the key factors in encouraging tourists' visitation and to spend time at a destination as well as significantly influencing a tourist's expected behaviour and destination image (Henkel et al., 2006; Reitsamer et al., 2016). The local community can complement natural and experiential resources in a destination. According to Kim et al. (2012), tourists who experience close encounters with local communities and the local culture are most likely to experience memorable tourism experiences that directly leads to higher tourists' satisfaction and generate a positive image of a destination which will likely result in a positive word of mouth publicity. Based on aforementioned, the following hypothesis is developed:

H1: Local communities' attitude has a positive effect on the destination image.

\section{Carrying Capacity}

From a general point of view, tourism capacity can be defined as the maximum number of people who can visit a tourist destination at the same time without causing the physical, economic and socio-cultural destruction and an unacceptable reduction in the quality of tourist satisfaction (Coccossis and Mexa, 2017). Carrying capacity is further defined as the environmental quality and visitor satisfaction that could not be diminished by the physical, biological, social and psychological capacity of the environment to support the visitant activity (Dioko and So, 2017). Past studies (Maggi and Fredella, 2010; Ndlovu and Chigora, 2019) have reported that an uncontrollable carrying capacity may destroy the environment and attractiveness of a tourism destination where it may result in the tourism destination losing its image to potential eco-tourists who are environmentally conscious as well as their future revisit intention and their level of satisfaction towards the destination (Joshi and Dahal, 2019). Besides, Wang et al. (2020) revealed that over-tourism of a destination can brings impacts to wider factors such as air quality and local environmental environments. The importance of carrying capacity may instrumental in the success of developing and creating a positive and memorable destination image (Yamagishi et al., 2020). Therefore, carrying capacity helps to maintain the balance between the benefits of a tourism destination and tourists' perception towards tourism activities. In light of the above discussion, the following hypothesis is developed:

$\mathrm{H} 2$ : Carrying capacity has a positive effect on the destination image.

\section{Destination Resources and Attractiveness}

Destination resources and attractiveness refer to attractions, attribute and resources and considerable diversity of items compounding the set of characteristics of the destination's offer (Vinyals-Mirabent, 2019; Enright and Newton; 2005; Hong-bumm, 1988). Reitsamer et al. (2016) state the uniqueness and attractiveness of the destination is based on tourists' insights about a destination and its ability to satisfy their satisfaction and needs. Past studies (Wong and Teoh, 2015; Zhang et al., 2014) have intensively explored the influence of this element on tourist's behavior, loyalty and revisit intention. Additionally, (Martín-Santana et al., 2017) revealed that destinations with various resources and attractiveness contribute to the formation of the overall impression and image of the destination in tourists' minds. Therefore, the destination's resources and attractiveness are crucial for both image formation and memorability of the staged destination experiences. The following hypothesis is proposed based on the above discussion:

H3: Destination resources and attractiveness have a positive effect on the destination image.

\section{Perceived Value}

The Moderating Role of Perceived Value on Local Communities' Attitude, Carrying Capacity and Destination Attractiveness and Resources on Destination Image

Perceived value is defined as the consumer's overall assessment of the utility of a product or service based on perceptions of what is received and what is given (Zeithaml, 1998). It can further recognize its role in predicting future behavioural intent and influencing competitive advantage as one of the most influential forces in the tourism industry (Bigne et al., 2009; Cheng et al., 2018). Previous study by Cheng and $\mathrm{Lu}$ (2013) confirmed that more favorable destination images are correlated with higher perceived value. Additionally, local community plays an important role by recommending the uniqueness of the destination and increase tourists' revisit intention (Cheng et al., 2018) while local attitude has been identified as a factor shaping the attractiveness of the destination (Gonzalez et al., 2018). Tourists are satisfied if they perceived the experience of what they expected (Dean et al., 2019).

Therefore, perceived value has a significant moderating impact on the relationship between local communities and destination image by reinforcing tourists' level of attitude and give rise to positive behavioural intention. In addition, a key perception in carrying capacity is the perception of overcrowding. Zhang et al. (2017) elucidated that uncontrollable carrying capacity of a destination may decrease tourists' satisfaction and expected needs. Thus, the perception of crowding may be thought as an attitude in which perception of an excessive use level of tourism and may lead to tourists' negativity perceived behavioural intention and will indirectly affect positive image of a destination (Gonzalez et al., 2018). Other than that, destination attractiveness and resources have been specified as the most important factors in strengthening destination image. Previous research has reported that tourists' perceived value of a destination would depend on the attractions that a destination provides on its positioning as a tourist destination (Michael et al., 2018). The refore, it is widely accepted that perceived value is important in promoting a long-term relationship with tourists proven by Wang et al. (2016) that it has a positive effect on the likelihood of revisiting and recommending the destination to others by increasing the positivity of a destination image. Based on the above discussion, the following hypotheses have been developed as follows: 
H4: The positive relationship between local communities' attitudes and destination image will be enhanced when the tourist's perceived value is high.

H5: The positive relationship between carrying capacity and destination image will be enhanced when the tourist's perceived value is high.

H6: The positive relationship between destination attractiveness \& resources and destination will be enhanced when the tourist's perceived value is high.

\section{MATERIALS AND METHODS}

A cross-sectional analysis was used in this research, in which results were used a self-administered questionnaire. All questionnaire items were adapted from previous studies and measured on a 7-point Likert-scale ranging from strongly disagree to strongly agree. In this analysis, local communities' attitudes were calculated using four elements (Collins, 2005; Tseane, 2006; Yusof and Rahman, 2011; Canny and Hidayat, 2012); carrying capacity was measured using four items (Artuğer, 2015); destination resources \& attractiveness were measured using four items (Kim et al., 2006; Maroofi and Dehghan, 2012; Oriade, 2013; Herstanti et al., 2014); destination image was measured using five items (Buhalis, 2000; Aliman et al., 2016); and the perceived value was measured using four items (Howard and Sheth, 1969; Apostolakis and Jaffry, 2005; Sanchez et al., 2006).

This study utilized G*Power Version 3.1.9.2 software to analyze and calculate the minimum sample size. Based on the calculations, a sample size of $103(\mathrm{~N}=103)$ is needed for this study with the power set at 0.80 , assuming a significance level of $5 \%$ and the effect size of $0.15 \mathrm{~A}$ pre-test was performed before a full-scale survey to detect any problems that respondents might encounter with the questionnaire items, such as unclear wording or other difficulties. WarpPLS 6.0 was applied based on path modeling to assess the model developed as shown in Figure 1 (Kock, 2017). A total of 400 questionnaires were distributed to examine the tourist's perception towards ecotourism development after they visited Bako National Park, Sarawak. In total, 146 valid responses were received, indicating a response rate of $36.5 \%$. $46.6 \%$ were male and $53.4 \%$ were female and most of the respondents were found between 21 to 30 years old $(52.1 \%) .38 .4 \%$ of the respondents are employed, $34.2 \%$ are students and $9.6 \%$ are running own business. Lastly, $41.8 \%$ of the respondents earned monthly income less than RM1500, $17.1 \%$ earned monthly income between RM4501 to RM6000 and 14.4\% earned monthly income ranged from RM3001 to RM4500.

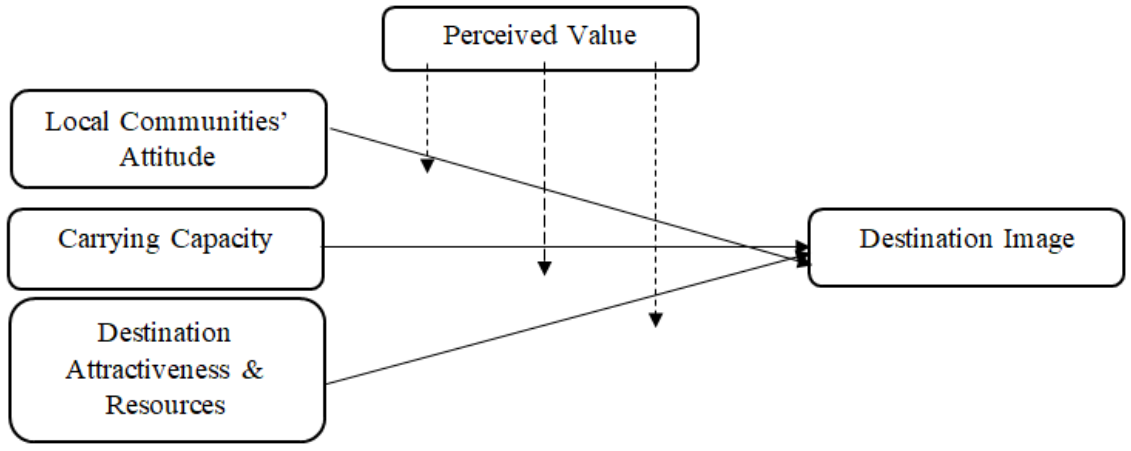

Figure 1. Research Model

\section{RESULTS AND DISCUSSION}

To analyze the proposed model, WarpPLS 6.0 software was applied. As suggested by Hair et al. (2017), this study tested the model using a two-stage approach. The first stage tests the measuring model, which involves evaluating the validity and reliability of the measuring components. The second stage involves the evaluation of the structural model, which enables assessment of the proposed relationships between the measurable constructs.

\section{Assessment of the measurement model}

The measurement model was examined by assessing the individual item reliability, construct reliability, convergent reliability and discriminant validity as all constructs in this study are modelled as reflective (Henseler et al., 2016). As shown in Table 1, all the factor loadings exceeded the minimum cut off point of 0.50 (Gefen et al., 2000), which thus signified the internal consistency as to be achieved.

Table 1. Summary of Construct Reliability and Validity

\begin{tabular}{|c|c|c|c|c|c|c|c|}
\hline Construct & No of Items & Items Deleted & Items & Loadings & AVE & CR & Cronbach's Alpha \\
\hline Local Communities Attitude & 4 & 1 & $\begin{array}{l}\text { LCA_1 } \\
\text { LCA_2 } \\
\text { LCA_4 }\end{array}$ & $\begin{array}{l}0.852 \\
0.844 \\
0.722 \\
\end{array}$ & 0.653 & 0.849 & 0.731 \\
\hline Carrying Capacity & 4 & 1 & $\begin{array}{l}\text { CC_2 } \\
\text { CC_3 } \\
\text { CC_4 } \\
\end{array}$ & $\begin{array}{l}0.817 \\
0.771 \\
0.658 \\
\end{array}$ & 0.565 & 0.795 & 0.611 \\
\hline $\begin{array}{l}\text { Destination Attractiveness } \\
\& \text { Resources }\end{array}$ & 4 & 0 & $\begin{array}{l}\text { SQ_DRA_1 } \\
\text { SQ_DRA_2 } \\
\text { SQ_DRA_3 } \\
\text { SQ_DRA_4 }\end{array}$ & $\begin{array}{l}0.725 \\
0.865 \\
0.879 \\
0.760 \\
\end{array}$ & 0.656 & 0.883 & 0.822 \\
\hline Perceived Values & 4 & 0 & $\begin{array}{l}\text { Values_1 } \\
\text { Valeus_2 } \\
\text { Values_3 } \\
\text { Values_4 } \\
\end{array}$ & $\begin{array}{l}0.832 \\
0.822 \\
0.819 \\
0.730 \\
\end{array}$ & 0.643 & 0.878 & 0.814 \\
\hline Destination Image & 5 & 0 & $\begin{array}{l}\text { DI_1 } \\
\text { DI_2 } \\
\text { DI_3 } \\
\text { DI_4 } \\
\text { DI_5 }\end{array}$ & $\begin{array}{l}0.724 \\
0.778 \\
0.752 \\
0.770 \\
0.669 \\
\end{array}$ & 0.555 & 0.862 & 0.799 \\
\hline
\end{tabular}


According to Sarstedt et al., (2014), construct reliability is considered adequate if the composite reliability (CR) and Cronbach's alpha values of the constructs are between 0.70 and 0.95 . The average variances extracted (AVE) should be more than 0.50 for adequate convergent validity. As presented in Table 1, all AVE values exceeded this threshold (Chin, 1998; Hair et al., 2014). Lastly, the discriminant validity was tested by using Fornell-Larcker criterion, in which the square root of AVE must be significantly greater than the variance shared between the construct and other constructs (Fornell and Larcker, 1981). Table 2 shows that all constructs have met the requirements of discriminant validity.

Table 2. Discriminant Validity of Constructs of HTMT of Measurement Model

\begin{tabular}{|c|c|c|c|c|c|}
\hline & Local Communities' Attitudes & Carrying Capacity & Attractiveness \& Resources & Perceived Value & Destination Image \\
\hline Local Communities' Attitudes & $\begin{array}{c}0.808 \\
\end{array}$ & & & & \\
\hline Carrying Capacity & 0.348 & 0.752 & & & \\
\hline Attractiveness \& Resources & 0.513 & 0.544 & 0.810 & & \\
\hline Destination Image & 0.446 & 0.537 & 0.543 & 0.599 & 0.745 \\
\hline
\end{tabular}

\section{Assessment of the structural model}

The structural model was assessed based on the significance of the structural path coefficients, the $\mathrm{R}^{2}$ values, the effect size of $f^{2}$ and the collinearity. Table 3 and Figure 2 display the results. Out of six hypotheses, four hypotheses were supported. There are three direct relationships supported namely, local communities' attitudes, carrying capacity and destination attractiveness \& resources, and one moderating effects relationship was supported. Specifically, the results of the statistical analysis support Hypothesis $1(\beta=0.204, p<0.005)$, Hypothesis $2(\beta=0.364, \mathrm{p}<0.001)$, Hypothesis $3(\beta=0.149, \mathrm{p}<0.032)$, Hypothesis $6(\beta=0.162, \mathrm{p}<0.022)$. In addition, the result shows that destination image $\left(\mathrm{R}^{2}=0.372\right)$ has weak value (Hair et al., 2017). On top of that, the variation inflation factor (VIF) values were obtained to test multicollinearity issue among the constructs. The results in Table 3 indicate that multicollinearity is not a concern in this study, as all VIF values are below the threshold of 5 (Hair et al., 2011).

Table 3. Summary of Path Coefficients and Hypotheses Testing (Include T-Values, Bias Corrected Confidence Intervals)

\begin{tabular}{|c|c|c|c|c|c|c|c|}
\hline Hypotheses & Relationship & $\beta$ & Std. Error & p-value & VIF & $f^{2}$ & Decision \\
\hline \multicolumn{8}{|c|}{ Direct Relationships } \\
\hline H1 & LCA->DI & 0.204 & 0.079 & 0.005 & 1.663 & 0.093 & Supported \\
\hline $\mathrm{H} 2$ & CC->DI & 0.364 & 0.076 & $<0.001$ & 1.651 & 0.198 & Supported \\
\hline $\mathrm{H} 3$ & SQ_DRA->DI & 0.149 & 0.080 & 0.032 & 2.486 & 0.081 & Supported \\
\hline \multicolumn{8}{|c|}{ Moderating Effects of Perceived Values } \\
\hline $\mathrm{H} 4$ & Values*LCA->DI & 0.108 & 0.081 & 0.091 & 1.656 & 0.043 & Not Supported \\
\hline H5 & Values*CC->DI & -0.265 & 0.078 & $<0.001$ & 1.868 & 0.112 & Not Supported \\
\hline H6 & Values*SQ_DRA->DI & 0.162 & 0.080 & 0.022 & 2.459 & 0.069 & Supported \\
\hline
\end{tabular}

Note: $* \mathrm{p}<0.05, * * \mathrm{p}<0.01$; LCA represents local communities' attitudes, CC represents carrying capacity,

SQ_DRA represents destination attractiveness \& resources, Values represents perceived values and DI represents destination image

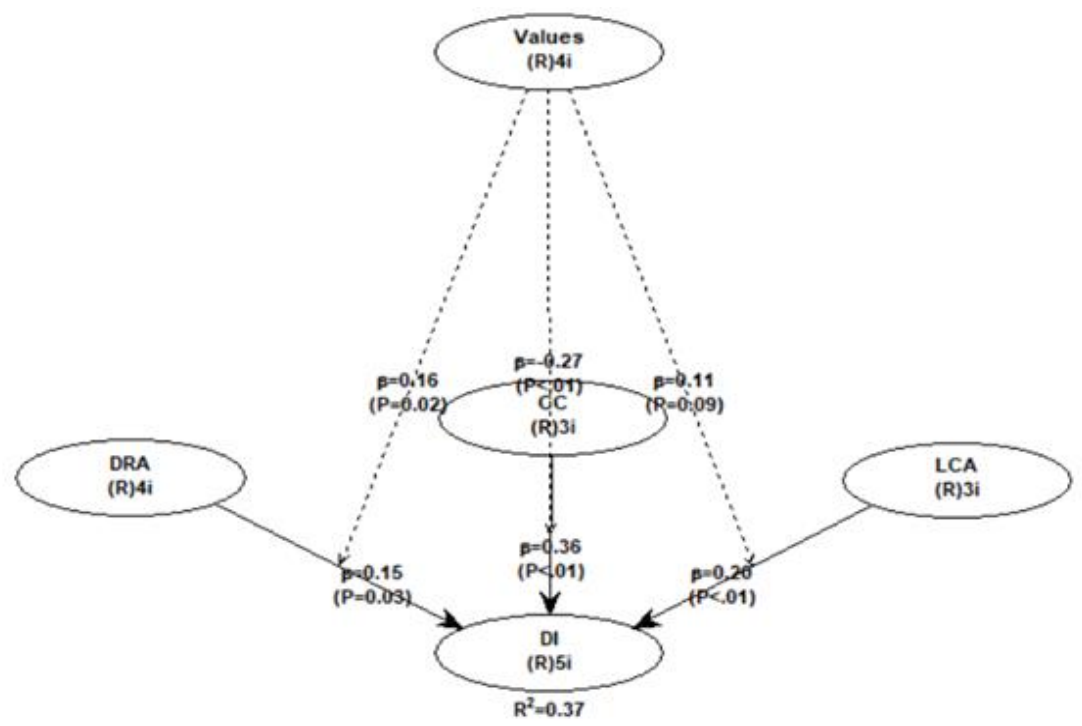

Figure 2. Results of Path Analysis

This study aims to examine the tourist's perceived value as a moderating role and destination image of Bako National Park, Sarawak as a tourist destination. Past studies have demonstrated that destination image is an important variable in the evaluations by tourists with respect to their travel experience and has an impact on their satisfaction (Toudert and Bringas-Rábago, 2016; Wang et al., 2017). In addition, the perceived value of tourists is seen as benefits of expected consumption.

Therefore, the perception of the tourists on the attributes of the destination and destination attractiveness will interact to shape the overall image of the destination (Susilowati and Sugandini, 2018). This study has adopted three independent variables, namely, local communities' attitudes, carrying capacity and destination attractiveness and resources, with perceived value as the moderator and destination image as the dependent variable. In summary, out of six tested hypotheses, four hypotheses were found to be supported.

As predicted, the empirical results showed that local communities' attitudes have had a significant impact on destination image, and thus supporting H1. Local communities have a better understanding of the destination politically and economically, instead of receiving unilateral information from the media (Isaac and Eid, 2019). Previous research by Mai et al., (2019) has proven that local community contributes to 
shape destination image by direct contact with tourists and help to enhance the attractiveness of the destination. Additionally, the results of this study indicated that carrying capacity has a positive impact on the destination image, indicating that $\mathrm{H} 2$ is supported. Carrying capacity is regarded as a way of providing sustainable management to a destination and is a crucial value to the conservation of vulnerable area such as national parks, protected area and heritage sites (Andrade, 2018). This is supported by past study (Andrade, 2018) that the carrying capacity of a destination will influence both destination image and tourist's revisit intention. Moreover, Reitsamer et al. (2016) indicated that attractiveness of destination is important for image formation and memorability of the destination experience. As such, the destination's popularity highly depends on its perceived prestige (Ram et al., 2016) as well as exclusive experiences that go beyond purchasing goods or services. This, therefore, underlines that intrapersonal authenticity has a positive influence on the image of the destination. In short, this indicated that tourist satisfaction will influence the attractiveness of the destination and in turn bring a positive image towards the destination.

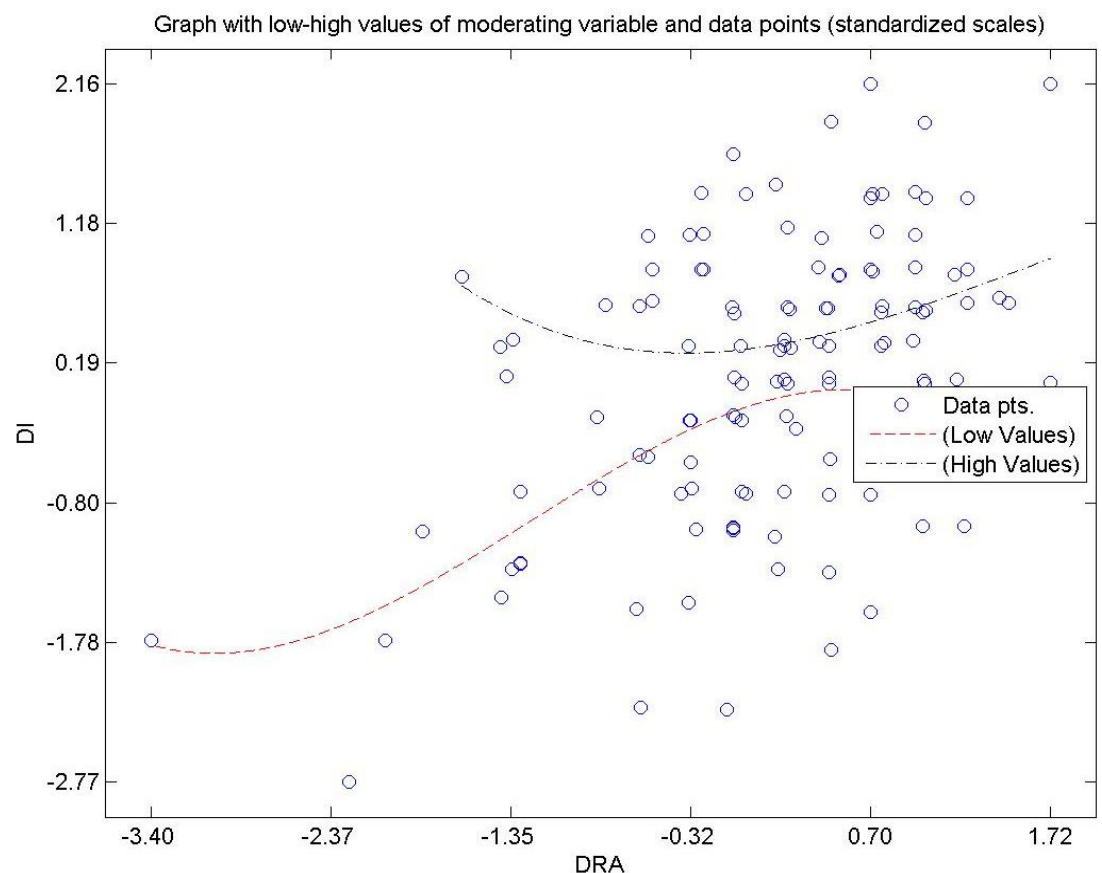

Figure 3. The Moderating Effect of Perceived Value on the Relationship between Destination Attractiveness and Resources and Destination Image

The statistical results further revealed that perceived value moderated the relationship between destination attractiveness a nd resources and destination image, thus supporting H6. Figure 3 showed the low-high values of the moderating effect of perceived value on the relationship between destination attractiveness and resources and destination image. The results indicated that the relationship between destination attractiveness and resources and tourism destination image is stronger when tourist perceived value is higher. According to Mura (2015), an exceptional resource and attractiveness of a destination may trigger a tourist's sensory stimula tion that leads to the deepest perceived experiences of existential genuineness. The destination at traction contributes to tourist's perceptible value by engaging in adventurous activities (Ram et al., 2016; Jiang et al., 2016). Therefore, destination attractiveness and resou rces through moderation support from tourist perceived value bring positive influences and image on the destination. On the other hand, the statistical results have also indicated that perceived value had no influence on the relationship between local communities' attitude and carrying capacity of tourism destination image, thus H4 and H5 are not supported. Plausible justification can be due to the tourists' themselves might think that the local community is not able to provide better and reliable information of their perceived destination and has no effect of giving positivity image towards the destination. Besides, tourists may think of the opinion that Bako National Park provides value as perceived by tourists in return. It can be concluded that this destination has fulfilled the demand of visitors and provides value experienced by tourists during their visits.

\section{CONCLUSION}

In summary, this study provides empirical evidence for the influence of local communities' attitudes, carrying capacity and destination attractiveness and resources on tourism destination image from tourist perception. In addition, perceived value is confirmed as a moderator moderating the relationship between destination attractiveness and resources and destination image. Both theoretical and practical implications and recommendations for future research are further discussed in this section.

From the theoretical implications, this study provided a comprehensive investigation into whether each antecedent such as local communities' attitudes, carrying capacity and destination attractiveness and resources as well as moderating variable, the perceived value on a sample of tourists at Bako National Park have substantiated the hypotheses in this study. From a practical point of view, the outcome of this study provides valuable information to tourism stakeholders and tourism planners about the importance of local communities' attitudes, carrying capacity and destination attractiveness and resources in the development of destination image. Therefore, tourism stakeholders, business operators, and tourism planners can focus on the prominence on these antecedents for effective implementation and development of ecotourism.

Nonetheless, there is some limitation that needs to be acknowledged. A tourism destination needs to maintain its positivity image of the destination to stay competitive and sustainable. Therefore, this research model may highlight other characteristics that could assist in building a stronger quantitative measure for destination image. In addition, it is possible not solely focusing on the view of the demand-side but also the perception view for the supply side. A wider concept and comprehensible perspective from different respondents such as tourism players should be integrated to get more accurate and precise results. For future studies, it is suggested to examine on tourist travel satisfaction and focus on more protected areas. Moreover, this study employed perceived value as the moderating variable to examine the relationship among the constructs. Future research may consider adopting another potential moderator variable and to test the framework. 


\section{Acknowledgement}

The funding for this project was made possible through the research grant [UHSB/B-AM2018/093] obtained from Sarawak Multimedia Authority and Universiti Malaysia Sarawak.

\section{REFERENCES}

Abas, S.A. \& Hanafiah, M.H. (2013). Local community attitudes towards tourism development in Tioman Island. In 6th Tourism Outlook Conference, Kota Kinabalu Sabah, Malaysia, pp. 22-24.

Aliman, N.K., Hashim, S.M., Wahid, S.D.M., \& Harudin, S. (2016). Tourists' Satisfaction with a Destination: An Investigation on Visitors to Langkawi Island. International Journal of Marketing Studies, 8(3), 173-188. https://doi.org/10.5539/ijms.v8n3p173

Andrades, L., \& Dimanche, F. (2017). Destination competitiveness and tourism development in Russia: Issues and challenges. Tourism Management, 62, 360376. http://doi.org/10.1016/j.tourman.2017.05.008

Apostolakis, A., \& Jaffry, S. (2005). A choice modeling application for Greek heritage attractions. Journal of Travel Research, 43(3), 309-318. https://doi.org/ $10.1177 \% 2 \mathrm{~F} 0047287504272035$

Artuğer, S. (2015). The effect of risk perceptions on tourists' revisit intentions. European Journal of Business and Management, 7(2), 36-43. http://citeseerx.ist.psu.edu/viewdoc/download?doi=10.1.1.912.1640\&rep=rep1\&type=pdf

Bigne, J.E., Sanchez, I., \& Andreu, L. (2009). The role of variety seeking in short and long run revisit intentions in holiday destinations. International Journal of Culture, Tourism and Hospitality Research, 3(2), 103-115. https://doi.org/10.1108/17506180910962113

Buckley, R. (2011). Tourism and environment. Annual Review of Environment and Resources, 36, 397-416. https://doi.org/10.1146/annurev-environ-041210-132637

Buhalis, D. (2000). Marketing the competitive destination of the future. Tourism Management, 21(1), 97-116. http://dx.doi.org/10.1016/S0261-5177(99)00095-3

Canny, I., \& Hidayat, N. (2012). The influence of service quality and tourist satisfaction on future behavioural intentions: The case study of Borobudur Temple as a UNESCO world culture heritage destination. International Proceedings of Economics Development \& Research, 50(19), 89-97. http://doi.org /10.13140/RG.2.1.1321.3043

Cheng, T.M., \& Lu, C.C. (2013). Destination image, novelty, hedonics, perceived value, and revisiting behavioural intention for island tourism. Asia Pacific Journal of Tourism Research, 18(7), 766-783. https://doi.org/10.1080/10941665.2012.697906

Cheng, Y.S., Kuo, N.T., Chang, K.C., \& Chen, C.H. (2019). How a tour guide interpretation service creates intention to revisit for tourists from mainland China: the mediating effect of perceived value. Journal of China Tourism Research, 15(1), 84-104. https://doi.org/10.1080/19388160.2018.1517067

Chin, C. (2019). Taking care of Malaysian tourism industry in the lead up to VM2020. The Star Online, 1. https://www.thestar.com.my/lifestyle/travel /2019/11/21/taking-care-of-malaysian-tourism-industry-in-the-lead-up-to-vm2020

Chin, C.H., Law, F.Y., Lo, M.C., \& Ramayah, T. (2018). The Impact of Accessibility Quality and Accommodation Quality on Tourists' Satisfaction and Revisit Intention to Rural Tourism Destination in Sarawak: The Moderating Role of Local Communities' Attitude. Global Business and Management Research, 10(2), 115-127. http://www.gbmrjournal.com/

Chin, W.W. (1998). The partial least squares approach for structural equation modeling. In G. A. Marcoulides (Ed.), Methodology for business and management. Modern Methods For business research (p. 295-336). Lawrence Erlbaum Associates Publishers.

Chiu, Y.T.H., Lee, W.I., \& Chen, T.H. (2014). Environmentally responsible behavior in ecotourism: Exploring the role of destination image and value perception. Asia Pacific Journal of Tourism Research, 19(8), 876-889. https://doi.org/10.1080/10941665.2013.818048

Coccossis, H., \& Mexa, A. (2017). The challenge of tourism carrying capacity assessment: Theory and practice. Routledge.

Collins, C. (2005). A smuggling approach to the passive in English. Syntax, 8(2), 81-120. https://doi.org/10.1111/j.1467-9612.2005.00076.x

Dean, D., Suhartanto, D., \& Kusdibyo, L. (2019). Predicting destination image in creative tourism: A comparative between tourists and residents. International Journal of Applied Business Research, 1(1), 1-15. https://doi.org/10.35313/ijabr.v1i01.36

Dioko, L.D.A., \& So, A.S. (2017). Residents' quality of life and visitors' quality of experience: Revisiting tourism carrying capacity in Macao. Worldwide Hospitality and Tourism Themes, 9(3), 349-360. http://dx.doi.org/10.1108/WHATT-02-2017-0006

Duffy, L.N., Kline, C., Swanson, J.R., Best, M., \& McKinnon, H. (2017). Community development through agroecotourism in Cuba: an application of the community capitals framework. Journal of Ecotourism, 16(3), 203-221. https://doi.org/10.1080/14724049.2016.1218498

Eagly, A.H. \& Chaiken, S. (1993). The psychology of attitudes. San Diego, California: Harcourt Brace Jovanovich College Publishers. https://doi.org/10. $1002 /$ mar.4220120509

Enright, M.J., \& Newton, J. (2005). Determinants of tourism destination competitiveness in Asia Pacific: Comprehensiveness and universality. Journal of Travel Research, 43(4), 339-350. https://doi.org/10.1177\%2F0047287505274647

Fornell, C.G., \& Larcker, D.F. (1981). Evaluating structural equation models with unobservable variables and measurement error. Journal of Marketing Research, 18(1), 39-50. https://doi.org/10.1177\%2F002224378101800104

Gefen, D., Straub, D., \& Boudreau, M.C. (2000). Structural equation modeling and regression: Guidelines for research practice. Communications of the association for information systems, 4(1), 7. https://doi.org/10.17705/1CAIS.00407

Gonzalez, V.M., Coromina, L., \& Galí, N. (2018). Overtourism: residents' perceptions of tourism impact as an indicator of resident social carrying capacitycase study of a Spanish heritage town. Tourism Review, 73(3), 277-296. https://doi.org/10.1108/TR-08-2017-0138

Hair, J.F., Hult, G.T.M., Ringle, C.M., \& Sarstedt, M. (2017). A primer on partial least squares structural equation modeling (PLS-SEM) (2nd ed.). Thousand Oaks, CA: Sage.

Hair, J.F., Hult, G.T.M., Ringle, C.M., \& Sarstedt, M. (2014). A primer on partial least squares structural equation modeling (PLS-SEM). Los Angeles: Sage Publication

Hair, J.F., Ringle, C.M., \& Sarstedt, M. (2011). PLS-SEM: Indeed a silver bullet. The Journal of Marketing Theory and Practice, 19(2), 139-152. https://doi.org/10.2753/MTP1069-6679190202

Henkel, R., Henkel, P., Agrusa, W., \& Tanner, J. (2006). Thailand as a tourist destination: Perceptions of international visitors and Thai residents. Asia Pacific Journal of Tourism Research, 11(3), 269-287. https://doi.org/10.1080/10941660600753299

Henseler, J., Hubona, G., \& Ray, P.A. (2016). Using PLS path modeling in new technology research: updated guidelines. Industrial Management \& Data Systems, 116(1), 2-20. https://doi.org/10.1108/IMDS-09-2015-0382

Herstanti, G., Suhud, U., \& Wibowo, S.F. (2014). Three modified models to predict intention of Indonesian tourists to revisit Sydney. European Journal of Business and Management, 6(25), 184-195. https://www.semanticscholar.org/paper/Three-Modified-Models-to-Predict-Intention-of-to-GhassaniWibowo/7f80d755d4337a519b31b2b8f6a0b1f7e2c53175

Hong-Bumm, K. (1998). Perceived attractiveness of Korean destinations. Annals of Tourism Research, 25(2), 340-361. http://dx.doi.org/10.1016/S01607383(98)00007-3

Howard, J.A., \& Sheth, J.N. (1969). The theory of buyer behaviour. New York: Jonh Wiley and Sons.

Isaac, R.K., \& Eid, T.A. (2019). Tourists' destination image: an exploratory study of alternative tourism in Palestine. Current Issues in Tourism, 22(12), 14991522. https://doi.org/10.1080/13683500.2018.1534806

Jamal, T., \& Budke, C. (2020). Tourism in a world with pandemics: local-global responsibility and action. Journal of Tourism Futures, 6(2), 181-188. https://doi.org/10.1108/JTF-02-2020-0014

Jiang, Y., Ramkissoon, H., Mavondo, F.T., \& Feng, S. (2017). Authenticity: The link between destination image and place attachment. Journal of Hospitality Marketing \& Management, 26(2), 105-124. https://doi.org/10.1080/19368623.2016.1185988

Joshi, S., \& Dahal, R. (2019). Relationship between Social Carrying Capacity and Tourism Carrying Capacity: A Case of Annapurna Conservation Area, Nepal. Journal of Tourism and Hospitality Education, 9, 9-29. https://doi.org/10.3126/jthe.v9i0.23677 
Kim, H.B., \& Lee, S. (2015). Impacts of city personality and image on revisit intention. International Journal of Tourism Cities, 1(1), 50-69. https://doi.org/10.1108/IJTC-08-2014-0004

Kim, H., Borges, M.C., \& Chon, J. (2006). Impacts of environmental values on tourism motivation: The case of FICA, Brazil. Tourism Management, 27(5), 957-967. https://doi.org/10.1016/j.tourman.2005.09.007

Kim, J., Ritchie, J.R.B., \& McCormick, B. (2012). Development of a scale to measure memorable tourism experiences. Journal of Travel Research, 51(1), 1225. https://doi.org/10.1177\%2F0047287510385467

Kladou, S., \& Mavragani, E. (2015). Assessing destination image: An online marketing approach and the case of TripAdvisor. Journal of Destination Marketing \& Management, 4(3), 187-193. https://doi.org/10.1016/j.jdmm.2015.04.003

Le, H., Le, T., Le, Q., \& Ngo, C. (2020). Examining the structural relationships of destination image and tourist satisfaction. Management Science Letters, 10(9), 1993-2000. http://dx.doi.org/10.5267/j.msl.2020.2.013

Lin, M.T.Y. (2019). Effects of Experiential Marketing on Experience Value and Customer Satisfaction in Ecotourism. Ekoloji Dergisi, 28(107), 3151-3156.

Maggi, E., \& Fredella, F.L. (2010). The carrying capacity of a tourist destination. The case of a coastal Italian city. 50th International Congress of European Regional Science Association (ERSA), Jonkoping. http://hdl.handle.net/10419/118917

Mai, X., Wu, C., Zhang, T., Zhou, Z., \& Zhong, H. (2019). The Impact of Local Community Participation on Branding Ethnic Tourism Destination: A Case Study of House Renovation in Jiaju Tibetan Village. Open Journal of Social Sciences, 7(01), 178-190. https://doi.org/10.4236/jss.2019.71016

Maroofi, F., \& Dehghan, S. (2012). Investigating the relationships of destination reflect, tourist satisfaction and destination loyalty. World Applied Sciences Journal, 19(8), 1160-1173. https://doi.org/10.5829/idosi.wasj.2012.19.08.1664

Martín-Santana, J.D., Beerli-Palacio, A., \& Nazzareno, P.A. (2017). Antecedents and consequences of destination image gap. Annals of Tourism Research, 62, 13-25. https://doi.org/10.1016/j.annals.2016.11.001

Michael, N., James, R., \& Michael, I. (2018). Australia's cognitive, affective and conative destination image: an Emirati tourist perspective. Journal of Islamic Marketing, 9(1), 36-59. https://doi.org/10.1108/JIMA-06-2016-0056

Michaelidou, N., Siamagka, N.T., Moraes, C., \& Micevski, M. (2013). Do marketers use visual representations of destinations that tourist's value? Comparing visitors' image of a destination with marketer-controlled images online. Journal of Travel Research, 52(6), 789-804. https://doi.org/ $10.1177 \% 2 \mathrm{~F} 0047287513481272$

Moon, H., \& Han, H. (2019). Tourist experience quality and loyalty to an island destination: The moderating impact of destination image. Journal of Travel \& Tourism Marketing, 36(1), 43-59. https://doi.org/10.1080/10548408.2018.1494083

Mura, P. (2015). Perceptions of authenticity in a Malaysian homestay-a narrative analysis. Tourism Management, 51, 225-233. https://doi.org/10.1016/j. tourman.2015.05.023

Ndlovu, J., \& Chigora, F. (2019). 9 The moderation effect of branding on destination image in a crisis-ridden destination, Zimbabwe. Tourism and Hospitality in Conflict-Ridden Destinations, 118-136. https://www.taylorfrancis.com/books/e/9780429463235/chapters/10.4324/9780429463235-9

Oriade, A.D. (2013). An empirical investigation of the relationship between perceived quality, value, satisfaction and behavioural intentions among visitors to UK attractions, Doctoral dissertation, University of Salford. http://usir.salford.ac.uk/id/eprint/29453

Ram, Y., Björk, P., \& Weidenfeld, A. (2016). Authenticity and place attachment of major visitor attractions. Tourism Management, 52, 110-122. https://doi.org/10.1016/j.tourman.2015.06.010

Reitsamer, B.F., Brunner-Sperdin, A., \& Stokburger-Sauer, N.E. (2016). Destination attractiveness and destination attachment: The mediating role of tourists attitude. Tourism Management Perspectives, 19, 93-101. https://doi.org/10.1016/j.tmp.2016.05.003

Sanchez, J., Callarisa, L., Rodriguez, R.M., \& Moliner, M.A. (2006). Perceived value of the purchase of a tourism product. Tourism Management, 27(3), 394409. https://doi.org/10.1016/j.tourman.2004.11.007

Sarstedt, M., Ringle, C.M., Smith, D., Reams, R., \& Hair, J.F. (2014). Partial least squares structural equation modeling (PLS-SEM): A useful tool for family business researchers. Journal of Family Business Strategy, 5(1), 105-115. https://doi.org/10.1016/j.jfbs.2014.01.002

Souiden, N., Ladhari, R., \& Chiadmi, N.E. (2017). Destination personality and destination image. Journal of Hospitality and Tourism Management, 32, 54-70. https://doi.org/10.1016/j.jhtm.2017.04.003

Susilowati, C., \& Sugandini, D. (2018). Perceived value, eWord-of-mouth, traditional word-of-mouth, and perceived quality to destination image of vacation tourists. Review of Integrative Business and Economics Research, 7, 312-321. https://www.sibresearch.org/uploads/3/4/0/9/34097180/riber_7-s1_sp_s17175_312-321.pdf

Tepavčević, J., Miljanić, U., Bradić, M., \& Janićević, S. (2019). Impact of London residents' sociodemographic characteristics on the motives for visiting national parks. Journal of the Geographical Institute" Jovan Cvijic", SASA, 69(2), 135-146. https://doi.org/10.2298/IJGI1902135T

Toudert, D., \& Bringas-Rábago, N.L. (2016). Impact of the destination image on cruise repeater's experience and intention at the visited port of call. Ocean \& Coastal Management, 130, 239-249. https://doi.org/10.1016/j.ocecoaman.2016.06.018

Tseane, L. (2006). Service quality in sport tourism: The case of the Berg River Canoe Marathon, Doctoral dissertation, Cape Peninsula University of Technology.

Veasna, S., Wu, W.Y., \& Huang, C.H. (2013). The impact of destination source credibility on destination satisfaction: The mediating effects of destination attachment and destination image. Tourism Management, 36, 511-526. https://doi.org/10.1016/j.tourman.2012.09.007

Vinyals-Mirabent, S. (2019). European urban destinations' attractors at the frontier between competitiveness and a unique destination image. A benchmark study of communication practices. Journal of Destination Marketing \& Management, 12, 37-45. https://doi.org/10.1016/j.jdmm.2019.02.006

Wang, B., Yang, Z., Han, F., \& Shi, H. (2017). Car tourism in Xinjiang: The mediation effect of perceived value and tourist satisfaction on the relationship between destination image and loyalty. Sustainability, 9(1), 22. https://doi.org/10.3390/su9010022

Wang, J., Huang, X., Gong, Z., \& Cao, K. (2020). Dynamic assessment of tourism carrying capacity and its impacts on tourism economic growth in urban tourism destinations in China. Journal of Destination Marketing \& Management, 15, 100383-100398. https://doi.org/10.1016/j.jdmm.2019.100383

Wong, P.P., \& Teoh, K. (2015). The influence of destination competitiveness on customer-based brand equity. Journal of Destination Marketing \& Management, 4(4), 206-212. https://doi.org/10.1016/j.jdmm.2015.05.001

Yamagishi, K.D., Tiu, A.M.C., Tanaid, R.A.B., Medalla, M.E.F., Jabilles, E.M.Y., Caballes, S.A.A., \& Ocampo, L.A. (2020). Characterizing Tourism Destination and Policies Forward: The Case in Bantayan Island, Philippines. Tourism Review International,24(2-3), 143-165. https://doi.org/ $10.3727 / 154427220 X 15912253254428$

Yusof, N.A., \& Rahman, F.A. (2011). Tourists' perceptions of service quality in a Lake-based tourism area. In Proceedings in International Conference on Business and Economics Research (IPEDR), 16, 84-89.

Zeithaml, V.A. (1988). Consumer perceptions of price, quality, and value: A means-end Model and synthesis of evidence. Journal of Marketing, 52(3), 2-22. https://doi.org/10.1177\%2F002224298805200302

Zhang, H., Fu, X., Cai, L.A., \& Lu, L. (2014). Destination image and tourist loyalty: A meta-analysis. Tourism Management, 40, 213-223. https://doi.org/10.1016/j.tourman.2013.06.006

Zhang, Y., Li, X.R., Su, Q., \& Hu, X. (2017). Exploring a theme park's tourism carrying capacity: A demand-side analysis. Tourism Management, 59, 564578. https://doi.org/10.1016/j.tourman.2016.08.019 